\title{
Package Dosing Unit
}

National Cancer Institute

\section{Source}

National Cancer Institute. Package Dosing Unit. NCI Thesaurus. Code C48520.

A dosing unit equal to the amount of active ing redient(s) contained in a package. 